\title{
Cities and Disturbed Areas as Man-made Shelters for Orchid Communities
}

\author{
Agnieszka REWICZ ${ }^{1 *}$, Anna BOMANOWSKA ${ }^{1}$, Myroslav V. SHEVERA², \\ Józef K. KUROWSKI ${ }^{1}$, Katarzyna KRASOŃ ${ }^{1}$, Katarzyna M. ZIELIŃSKA ${ }^{1}$ \\ ${ }^{1}$ University of Lodz, Faculty of Biology and Environmental Protection, Department of Geobotany and Plant Ecology, \\ 12/16 Banacha Str., 90 - 237Lodz, Poland; agnieszka.rewicz@biol.uni.lodz.pl ("correspondingauthor); \\ anna.bomanowska@biol.uni.lodz.pl;jozef.kurowski@biol.uni.lodz.pl;kasia11251@gmail.com; katarzyna.zielinska@biol.uni.lodz.pl \\ ${ }^{2}$ National Academy of Science of Ukraine, Department of Systematics and Floristics of Vascular Plants, M.G. Kholodny Institute of Botany, \\ 2 Tereshchenkivska Str., 01601 Kyiev,Ukraine; shevera.myroslav@gmail.com
}

\begin{abstract}
Many species from the family Orchidaceae spread in anthropogenic habitats and numerous studies documenting this process are known. Unfortunately, such data are scattered throughout various papers and reports, sometimes fragmentary and hard to reach (the 'grey literature'). Scientific elaboration on this topic still lacks a comprehensive review and summary of the scale of this phenomenon. Therefore, the main aim of this study was to gather, review and analyse such data, seeking the answer to the question whether the man-made habitats can be considered as refugee for orchids. The paper summarises data on the occurrence of orchid species in man-made habitats in Europe originating from published and unpublished sources. The particular emphasis was placed in urban habitats. For this purpose, the floristically data from 42 European cities were used. The conducted studies showed that the apohytism phenomenon in the family Orchidaceae was more widespread than had been previously reported. As a result, 70 species of orchids in the distinguished man-made habitats were found. The majority of the species grow on sand and clay pits. The most common species were Epipactis helleborine and Dactylorhiza majalis. The gathered data have confirmed that man-made habitats become refugee for many orchid species in the aftermath of the loss of their natural habitats. Thus, protection of sites transformed by man with orchid occurrence should be taken into consideration. These sites can become a source of very useful information for biogeographically and phylo-geographically analyses of many valuable and endangered species.
\end{abstract}

Keywords: anthropogenous habitats, apophytism, Orchidaceae, urban areas, species diversity

\section{Introduction}

Increasing anthropogenic impact on the environment and the related environmental transformation may result in the shrinking of areas of natural habitats or in the creation of substitute habitats novel in terms of ecological conditions (Jongman, 2002; Walker, 2007; Brun, 2009; Lundholm and Richardson 2010; Yamaura et al., 2012). Plants often respond to the anthropogenic pressure by e.g.: a decline in the number of localities; the disappearance of entire populations; the breakdown of ecological connections, as well as changes of morphological and genetic diversity (Andrews, 1990; Hollingsworth and Dickson, 1997; Vitousek et al., 1997; Reisch, 2006; Walker, 2007; Van Calster et al., 2008; Niedrist et al., 2009; Rewicz et al., 2016; Zielińska et al., 2016). However, a couple of indigenous species found suitable conditions in anthropogenic habitats (Formant et al., 2009; Efimov, 2011; van Kleef et al., 2012; Yamaura et al., 2012). Those new habitats, often created by man, give many plant species a chance to survive. Moreover, the most flexible species may increase the number of localities and expand within, even outside the original geographical range.

It has been stated that anthropogenic habitats are colonised mainly by indigenous flora, characteristic of a given area (Piekarska-Stachowiak et al., 2014). This process of spreading native species to human-made habitats is called apophytism (Jackowiak, 2006; Sukopp, 2006, 2008). In the rich literature concerning the influence of human disturbance on flora, there are many papers devoted to indigenous plant species spontaneously expanding in man-made habitats named apophytes (Kowarik, 1991; Jackowiak, 2006; Sukopp, 2006, 2008). 
Generally, man-made areas are settled by common species demonstrating wide tolerance to habitat conditions (Latzel $e t$ al., 2011; Piekarska-Stachowiak et al., 2014). However, disturbed habitats could also function as a refuge for rare and endangered plants (Greenwood and Gemmell, 1978; Heindl and Ullmann, 1991; Ullmann et al., 1998; Brändle et al., 2003; Nowak, 2005, 2006; Nowak and Nowak, 2006; Esfeld et al., 2008; Kirpluk and Bomanowska, 2008; Reisch, 2006; van Kleef et al., 2012; Zielińska et al., 2016). Surprisingly, orchids are often found in the apophytes group, but they are still one of the most threatened plant groups in the world (Sharrock and Jones, 2009; Bliz et al., 2011; The IUCN Red List of Threatened Species 2015). The disappearance of natural habitats of orchids is well documented. Industrialisation and the related urbanisation are transforming natural habitats with side effects such as air, soil and water pollution, which are responsible for reducing orchid populations (McCormick et al., 2004; Pfeifer and Jetschke, 2006; Sukopp, 2006; Rewicz et al., 2015). On the other hand, numerous studies have revealed that some orchid species were found in a great number of individuals in anthropogenous habitats that were either grossly modified by man or entirely man-made (Davis, 1979; Adamowski and Conti, 1991; Hollingsworth and Dickson, 1997; Adamowski, 2002, 2006; Heyde and Krug, 2000; Ehlers et al., 2002; Klimko et al., 2004; Light and MacConaill, 2005, 2006; Witting and Witting, 2007; Esfeld et al., 2008; Pedersen et al., 2013; Rewicz et al., 2016). Members of the family Orchidaceae can be found in varius types of anthropogenic habitats e.g.: roadsides, waste dumps, railway embankments, canal banks, poplar plantations, gravel pits, chalk and limestone quarries, lignite mining areas, etc. (e.g.: Davis, 1979; Adamowski, 2006; Esfeld et al., 2008). Such behaviour has been observed since the 19th century, when orchids were noticed on railway embankment and in sand limestone excavations in the United Kingdom for the first time (Prochazka and Velisek, 1983). According to Adamowski (2006), 53 orchid species occur in anthropogenically altered habitats, which is about $40 \%$ of the entire European flora of these plants. The most common taxa spread in secondary habitats in temperate Europe are species from the genus Epipactis and Dactylorrbiza. Those orchids have a shorter life cycle and broader ecological amplitudes in comparison to the other taxa (Adamowski, 2006).

Recently, in the scientific literature there are more and more reports indicating the appearance of orchids in urban areas (e.g.: Chronopoulos and Christodoulakis, 1996; Heinrich and Dietrich, 2008; Stefaniak et al., 2011; Barrico et al., 2012; Milović and Mitić, 2012; Tafra et al., 2012; Maslo, 2014; Stešević et al., 2014). This phenomenon needs special attention as towns and cities are a kind of conglomerates of transformed habitats which are not in the immediate vicinity of habitats natural for the analysed species.

Although the phenomenon of orchid species spreading onto transformed areas has been known for a long time and has been widely reported, there is a lack of research papers summarising the state of knowledge concerning this process. Therefore, the aim of the undertaken study was to complete the scattered data and to review the available information related to orchid species occurring in various man-made habitats, with a particular focus on urban habitats across
Europe. In this paper, recent as well as historical data about orchids occurring in man-made habitats were reviewed to draw attention to this phenomenon and to provide a basis for future research. Besides the predominant review function of this paper, the final data set was used to address the question whether transformed areas can be important substitute sites for orchid species endangered in their natural landscape, and also to define the spectrum of anthropogenic habitats occupied by the species.

\section{Materials and Methods}

\section{Data sources}

The complete list of orchid species occurring in man-made habitats was prepared based on available literature data, including information published in scientific articles and data from the "grey literature", such as local monographs or technical reports. The paper included all types of anthropogenic habitats where orchids were found. The analyses covered only such species of orchids which had the apophyte status in the city i.e. native plants established in anthropogenic habitats (Jackowiak, 2006; Sukopp, 2006). We did not take into account species found in nontransformed areas which sometimes lie inside the urban areas, for example: protected areas or forest complexes located within administrative boundaries of cities. The distinguished anthropogenic habitats were grouped into eight categories: (A) forests influenced by industrial emissions; (B) industrial terrains; (C) industrial waste places; (D) greenery - parks, hedges, etc.; (E) plantations of ecologically alien trees; (F) plantations of nonnative trees; $(\mathrm{G})$ roadsides and embankments; $(\mathrm{H})$ sand pits, clay pits and quarries.

For the analysis of occurrence of orchids in urban habitats, we selected available materials comprising complete lists of urban flora of 42 European cities, mainly from the area of Central and Northern Europe (Table 1).

Orchids occurring in urban habitats were grouped into frequency classes of the following categories (the number of occurrences of the species in all of the cities): I - up to $20 \%$, II 20-39\%, III - 40-59\%, IV - 60-79\%, V - 80-100\%.

Due to somewhat diversified extent of floristic studies carried out at various locations, data on species occurrence was encoded in a binary fashion (0-1, absent-present), without taking into account the degrees of quantitative occurrence.

Species nomenclature was adopted from Delforge (2006).

\section{Data analysis}

Spearman's rank correlation coefficients were used for the analysis of the correlation between the area of the examined cities and the number of orchid species and between the total numbers of vascular plants in particular cities and the number of orchids. The results were considered to be statistically significant for $\mathrm{p}<$ 0.05 . The Detrended Correspondence Analysis (DCA) was used to assess variability within individual habitats in terms of occurrence of species from the Orchidaceae family. The software package STATISTICA PL. ver. 10 and Canoco ver. 4.5 were used for all the above-mentioned numerical analyses (Statsoft Inc, 2013; Leps and Smilauer, 2003).

\section{Results}

\section{Orchidaceae in anthropogenic habitats}

As a result, 70 species of orchids in the investigated man- 
128

Table 1. List of cities in which orchid species on man-made habitats were noted

\begin{tabular}{|c|c|c|c|c|}
\hline No. & City & Country & GPScoordinates & Source of data \\
\hline 1. & Helsinki & Finland & $60^{\circ} 10^{\prime} 12.0^{\prime \prime} \mathrm{N} 24^{\circ} 56^{\prime} 18.4^{\prime \prime} \mathrm{E}$ & Vähä-Piikkiö et al., 2004 \\
\hline 2. & Sankt Petersburg & Russia & $59^{\circ} 56^{\prime} 0^{\prime \prime} \mathrm{N}, 30^{\circ} 16^{\prime} 0^{\prime \prime} \mathrm{E}$ & Ignatieva and Konechnaya, 2004 \\
\hline 3. & Jena & Germany & $50^{\circ} 56^{\prime} 0^{\prime \prime} \mathrm{N}, 11^{\circ} 35^{\prime} 0^{\prime \prime} \mathrm{E}$ & Heinrich and Dietrich, 2008 \\
\hline 4. & Wałbrzych & Poland & $50^{\circ} 46^{\prime} 15^{\prime \prime} \mathrm{N}, 16^{\circ} 16^{\prime} 26^{\prime \prime} \mathrm{E}$ & Klimko et al., 2004 \\
\hline 5. & Czeladź & Poland & $50^{\circ} 19^{\prime} 2^{\prime \prime} \mathrm{N}, 19^{\circ} 4^{\prime} 13^{\prime \prime} \mathrm{E}$ & Tokarska-Guzik and Rostański, 1998 \\
\hline 6. & Katowice & Poland & $50^{\circ} 15^{\prime} 51^{\prime \prime} \mathrm{N}, 19^{\circ} 1^{\prime} 25^{\prime \prime} \mathrm{E}$ & Tokarska-Guzik and Rostański, 1997 \\
\hline 7. & Jaworzno & Poland & $50^{\circ} 12^{\prime} 16^{\prime \prime} \mathrm{N}, 19^{\circ} 16^{\prime} 12^{\prime \prime} \mathrm{E}$ & Tokarska-Guzik, 1997 \\
\hline 8. & Szczytno & Poland & $53^{\circ} 33^{\prime} 46^{\prime \prime} \mathrm{N}, 20^{\circ} 59^{\prime} 7^{\prime \prime} \mathrm{E}$ & Środa, 2002 \\
\hline 9. & Warszawa & Poland & $52^{\circ} 13^{\prime} 56^{\prime \prime} \mathrm{N}, 21^{\circ} 0^{\prime} 30^{\prime \prime} \mathrm{E}$ & Sudnik-Wójcikowska, 1987 \\
\hline 10. & Poznań & Poland & $52^{\circ} 24^{\prime} 30^{\prime \prime} \mathrm{N}, 16^{\circ} 56^{\prime} 3^{\prime \prime} \mathrm{E}$ & Jackowiak, 1993 \\
\hline 11. & Łódź & Poland & $51^{\circ} 46^{\prime} 36^{\prime \prime} \mathrm{N}, 19^{\circ} 27^{\prime} 17^{\prime \prime} \mathrm{E}$ & Witosławski, 2006 \\
\hline 12. & Bielsk Podlaski & Poland & $52^{\circ} 46^{\prime} 6^{\prime \prime} \mathrm{N}, 23^{\circ} 11^{\prime} 31^{\prime \prime} \mathrm{E}$ & Wołkowycki, 2003 \\
\hline 13. & Koszalin & Poland & $54^{\circ} 11^{\prime} 25^{\prime \prime} \mathrm{N}, 16^{\circ} 10^{\prime} 54^{\prime \prime} \mathrm{E}$ & Ćwikliński, 1971 \\
\hline 14. & Słupsk & Poland & $54^{\circ} 27^{\prime} 57^{\prime \prime} \mathrm{N}, 17^{\circ} 1^{\prime} 45^{\prime \prime} \mathrm{E}$ & Misiewicz, 1978 \\
\hline 15. & Działoszyn & Poland & $51^{\circ} 7^{\prime} 4^{\prime \prime} \mathrm{N}, 18^{\circ} 52^{\prime} 12^{\prime \prime} \mathrm{E}$ & Suwara-Szmigielska, 2010 \\
\hline 16. & Warta & Poland & $51^{\circ} 42^{\prime} 29^{\prime \prime} \mathrm{N}, 18^{\circ} 37^{\prime} 30^{\prime \prime} \mathrm{E}$ & Suwara-Szmigielska, 2010 \\
\hline 17. & Głogówek & Poland & $50^{\circ} 20^{\prime} 38^{\prime \prime} \mathrm{N}, 17^{\circ} 52^{\prime} 2^{\prime \prime} \mathrm{E}$ & Szotkowski, 1987 \\
\hline 18. & Kraków & Poland & $50^{\circ} 3^{\prime} 41^{\prime \prime} \mathrm{N}, 19^{\circ} 56^{\prime} 18^{\prime \prime} \mathrm{E}$ & Trzcińska-Tacik, 1979 \\
\hline 19. & Uzhgorod & Ukraine & $48^{\circ} 37^{\prime} 26^{\prime \prime} \mathrm{N}, 22^{\circ} 17^{\prime} 42^{\prime \prime} \mathrm{E}$ & Protopopova and Shevera, 2002 \\
\hline 20. & Chernivtsi & Ukraine & $48^{\circ} 18^{\prime} 0^{\prime \prime} \mathrm{N}, 25^{\circ} 56^{\prime} 0^{\prime \prime} \mathrm{E}$ & Korzhan, 2011 \\
\hline 21. & Netishyn & Ukraine & $50^{\circ} 21^{\prime} 0^{\prime \prime} \mathrm{N}, 26^{\circ} 38^{\prime} 0^{\prime \prime} \mathrm{E}$ & Gubar, 2006 \\
\hline 22. & Kostopil & Ukraine & $50^{\circ} 53^{\prime} 0^{\prime \prime} \mathrm{N}, 26^{\circ} 27^{\prime} 0^{\prime \prime} \mathrm{E}$ & Gutsmam, 2013 \\
\hline 23. & Berezne & Ukraine & $50^{\circ} 59^{\prime} 48^{\prime \prime} \mathrm{N}, 26^{\circ} 44^{\prime} 22^{\prime \prime} \mathrm{E}$ & Gutsmam, 2013 \\
\hline 24. & Kamianets-Podilskyi & Ukraine & $48^{\circ} 41^{\prime} 0^{\prime \prime} \mathrm{N}, 26^{\circ} 35^{\prime} 0^{\prime \prime} \mathrm{E}$ & Levanet $\widehat{s}$ et al., 2004 \\
\hline 25. & Kuznetsovsk & Ukraine & $51^{\circ} 20^{\prime} 40^{\prime \prime} \mathrm{N}, 25^{\circ} 51^{\prime} 3^{\prime \prime} \mathrm{E}$ & Gutsmam, 2013 \\
\hline 26. & Dubrovytsya & Ukraine & $51^{\circ} 34^{\prime} 0^{\prime \prime} \mathrm{N}, 26^{\circ} 34^{\prime} 0^{\prime \prime} \mathrm{E}$ & Gutsmam, 2013 \\
\hline 27. & Simferopol & Ukraine & $44^{\circ} 57^{\prime} 7^{\prime \prime} \mathrm{N}, 34^{\circ} 6^{\prime} 8^{\prime \prime} \mathrm{E}$ & Iepikhin, 2008 \\
\hline 28. & Shepetovka & Ukraine & $50^{\circ} 11^{\prime} 0^{\prime \prime} \mathrm{N}, 27^{\circ} 4^{\prime} 0^{\prime \prime} \mathrm{E}$ & Gubar, 2006 \\
\hline 29. & Vinnytsya & Ukraine & $49^{\circ} 14^{\prime} 0^{\prime \prime} \mathrm{N}, 28^{\circ} 29^{\prime} 0^{\prime \prime} \mathrm{E}$ & Dobrovolska, unpub. \\
\hline 30. & Kharkiv & Ukraine & $50^{\circ} 0^{\prime} 16^{\prime \prime} \mathrm{N}, 36^{\circ} 13^{\prime} 53^{\prime \prime} \mathrm{E}$ & Zvyagintseva, 2013 \\
\hline 31. & Kirovohrad & Ukraine & $48^{\circ} 30^{\prime} 0^{\prime \prime} \mathrm{N}, 32^{\circ} 16^{\prime} 0^{\prime \prime} \mathrm{E}$ & Arkushyna and Popova, 2010 \\
\hline 32. & Chernihiv & Ukraine & $51^{\circ} 30^{\prime} 0^{\prime \prime} \mathrm{N}, 31^{\circ} 18^{\prime} 0^{\prime \prime} \mathrm{E}$ & Zavyalova, 2010 \\
\hline 33. & Pereyaslav-Khmelnytsky & Ukraine & $50^{\circ} 3^{\prime} 58^{\prime \prime} \mathrm{N}, 31^{\circ} 26^{\prime} 32^{\prime \prime} \mathrm{E}$ & Kotsur et al., 2010 \\
\hline 34. & Coimbra & Portugal & $40^{\circ} 15^{\prime} 0^{\prime \prime} \mathrm{N}, 8^{\circ} 27^{\prime} 0^{\prime \prime} \mathrm{E}$ & Barrico et al., 2012 \\
\hline 35. & Rome & Italy & $41^{\circ} 54^{\prime} 0^{\prime \prime} \mathrm{N}, 12^{\circ} 30^{\prime} 0^{\prime \prime} \mathrm{E}$ & Celesti-Grapow et al., 2013 \\
\hline 36. & Mostar & Bosnia and Herzegovina & $43^{\circ} 20^{\prime} 0^{\prime \prime} \mathrm{N}, 17^{\circ} 48^{\prime} 0^{\prime \prime} \mathrm{E}$ & Maslo, 2014 \\
\hline 37. & Zadar & Croatia & $44^{\circ} 6^{\prime} 51^{\prime \prime} \mathrm{N}, 15^{\circ} 13^{\prime} 40^{\prime \prime} \mathrm{E}$ & Milović and Mitić, 2012 \\
\hline 38. & Omiš & Croatia & $43^{\circ} 26^{\prime} 41^{\prime \prime} \mathrm{N}, 16^{\circ} 41^{\prime} 19^{\prime \prime} \mathrm{E}$ & Tafra et al., 2012 \\
\hline 39. & Podgorica & Montenegro & $42^{\circ} 26^{\prime} 2^{\prime \prime} \mathrm{N}, 19^{\circ} 15^{\prime} 4^{\prime \prime} \mathrm{E}$ & Stešević et al., 2014 \\
\hline 40. & Thessaloniki & Greece & $40^{\circ} 39^{\prime} 0^{\prime \prime} \mathrm{N}, 22^{\circ} 54^{\prime} 0^{\prime \prime} \mathrm{E}$ & Krigas and Kokkini, 2005 \\
\hline 41. & Patras & Greece & $38^{\circ} 15^{\prime} 0^{\prime \prime} \mathrm{N}, 21^{\circ} 44^{\prime} 0^{\prime \prime} \mathrm{E}$ & Chronopoulos and Christodoulakis, 1996 \\
\hline
\end{tabular}

made habitats were recorded (Table 2). The most common orchids occurring in the analysed anthropogenic sites were species from the genus Epipactis - E. helleborine, which occurred in all the types (8) of habitats, E. atrorubens recorded in six various habitats, and E. palustris observed in five (Fig. 1).

Numerous species were found in sand pits, clay pits, quarries (48), as well as on roadsides and embankments (35; Table 2). The most common species of orchids in these habitats were: E. helleborine (34) recorded 17 times on roadsides and embankments, E. palustris (18) recorded eight times in sand pits, clay pits and quarries, and E. atrorubens (18) recorded seven times on roadsides and embankments (Fig. 2).

The Detrended Correspondence Analysis (DCA) showed a group of species (E. helleborine, L. ovata, D. majalis, D. fuschii, N. nidus-avis, P. bifolia and P. chlorantha) most attached to six types of habitats. The first axis explains $28 \%$ of variability and the second axis $41 \%$ respectively (Fig. 3 ).

Orchidaceae in urban areas

In 42 analysed cities, 79 species of the Orchidaceae family, which belong to 25 genera, were found. The majority of the species (17) belong to the genus Ophrys, 12 to the genus Dactylorbiza and 8 to the genus Epipactis respectively.

The number of occurrences of orchids in the cities ranged from 1 up to 33. The largest numbers of species of orchids were reported in Rome (33), and also in Chernivtsi (23), Podgorica (20), and Warsaw (19). In ten cities, only one species of Orchidaceae was found (Table 3).

The analysis of the frequency classes of the particular taxa occurrences showed that the majority of the specimens belong to the first two classes of frequency: 54 species belong to the I class and 14 to the II class (Table 3). Only four species: Epipactis helleborine, Dactylorbiza incarnata, Listera ovata and Platantera bifolia belong to the most frequent classes (IV-V; Table 3).

The most common species in the examined cities were: $E$. helleborine - reported in 21 cities, D. incarnata (16), L. ovata (13), P. bifolia (14) and D. majalis (12; Table 3). As many as 27 species of orchids were found merely in one city, e.g: Orchis simia, O. provincialis, Ophrys sphegodes, O. mamosa, O. lutea, $O$. 
insectifera, Himantoglossum bircinum and H. caprinum.

The correlation between the area of the cities and the number of orchid species $(\mathrm{r}=0.1871)$ and between the number of all the species and the number of the orchid species in the city $(r=-0.1571)$ was not very strong and statistically not significant in each case (Spearman's rank correlation, $\mathrm{p}<0.05$ ).

\section{Discussion}

A quite high number of species detected in anthropogenic habitats, including urban ones, confirms that the phenomenon of apophytism is widespread among orchids. The most commonly quoted orchids which occur in man-made habitats

Table 2. Orchids species noted in distinguished man-made habitats

\begin{tabular}{|c|c|}
\hline Species & Source \\
\hline \multicolumn{2}{|l|}{ A - forests influenced by industrial emissions ( $N=6$ species $)$} \\
\hline Goodyera repens (L.) R. Br. & Świercz, 2004, 2005, 2006, 2007 \\
\hline Epipactis atrorubens (Hoffm.) Besser & Świercz, 2004, 2005, 2006, 2007; Nissalo M, correspondence \\
\hline Epipactis helleborine (L.) Crantz & Świercz, 2004, 2005, 2006, 2007 \\
\hline Malaxis monophyllos (L.) Sw. & Bernacki, 1987; Bróż and Maciejczak, 1991 \\
\hline Ophrys apifera Huds. & Nissalo M, correspondence \\
\hline Platanthera bifolia (L.) Rich. & Świercz, 2004, 2005, 2006, 2007 \\
\hline \multicolumn{2}{|l|}{$B$ - industrial terrains $(\mathrm{N}=4$ species $)$} \\
\hline Epipactis atrorubens (Hoffm.) Besser & Misiewicz, 1976 \\
\hline Epipactis helleborine (L.) Crantz & Misiewicz, 1976; Rebele, 1988 \\
\hline Epipactis palustris (L.) Crantz & Misiewicz, 1976 \\
\hline Listera ovata (L.) R. Br. & Rebele, 1988 \\
\hline \multicolumn{2}{|l|}{$C$ - industrial waste places $(\mathrm{N}=12$ species $)$} \\
\hline Anacamptis pyramidalis (L.) Rich. & Sinker et al., 1991 \\
\hline Dactylorhiza incarnata (L.) Soó & Greenwood and Gemmel, 1978 \\
\hline Dactylorbiza praetermissa (Druce) Soó & Greenwood and Gemmel, 1978 \\
\hline Dactylorhiza purpurella (T. Stephenson and T.A. Stephenson) Soó & Greenwood and Gemmel, 1978 \\
\hline Epipactis atrorubens (Hoffm.) Besser & Jurkiewicz et al., 2001; Woch, 2012 \\
\hline Epipactis helleborine (L.) Crantz & Remmel, 1970; Klimko et al., 2004 \\
\hline Epipactis palustris (L.) Crantz & Greenwood and Gemmel, 1978; Rostański and Michalska, 2003; Błońska, 2010 \\
\hline Gymnadenia conopsea (L.) R.Br. subsp. conopsea & Greenwood and Gemmel, 1978 \\
\hline Ophrys apifera Huds. & Greenwood and Gemmel, 1978 \\
\hline Orchis mascula L. & Sarosiek J, correspondence \\
\hline Orchis morio L. & Greenwood and Gemmel, 1978 \\
\hline Zeuxine strateumatica (Linnaeus) Schlechter & Siu and Chau, 1998 \\
\hline \multicolumn{2}{|l|}{$D$ - parks, hedges etc. greenery $(\mathrm{N}=9$ species $)$} \\
\hline Dipodium roseum D.L. Jones and M.A. Clem. & Jolly, 1998 \\
\hline Epipactis helleborine (L.) Crantz & Sinker et al., 1991; Godefroid, 1995; Wittig and Wittig, 2007 \\
\hline Eulophia sinensis Miq. & Sun, 1997 \\
\hline Jacquiniella teretifolia (Sw.) Britton and P. Wilson & Solis-Montero et al., 2005 \\
\hline Maxillaria densa Lindl. & Solis-Montero et al., 2005 \\
\hline Scaphyglottis livida (Lindl.) Schltr. & Solis-Montero et al., 2005 \\
\hline Spiranthes hongkongensis S. Y. Hu et Barretto & Sun, 1997 \\
\hline Spiranthes spiralis (L.) Chevall. & Sinker et al., 1991 \\
\hline Zeuxine strateumatica (Linnaeus) Schlechter & Sun, 1997 \\
\hline \multicolumn{2}{|l|}{ E - plantations of ecologically alien trees $(\mathrm{N}=8$ species $)$} \\
\hline Cephalanthera longifolia (L.) Fritsch & Burda, 1998; Berezutsky et al., 2014 \\
\hline Cephalanthera rubra (L.) Rich. & Conti, 1987; Berezutsky et al., 2014 \\
\hline Epipactis atrorubens (Hoffm.) Besser & Berezutsky et al., 2014 \\
\hline Epipactis helleborine (L.) Crantz & Berezutsky et al., 2014 \\
\hline Epipactis microphylla (Ehrh.) Sw. & Conti, 1987 \\
\hline Neottia nidus-avis (L.) L.C.M.Rich & Berezutsky et al., 2014 \\
\hline Ophrys apifera Huds. & Conti, 1987 \\
\hline Platanthera bifolia (L.) Rich. & Berezutsky et al., 2014 \\
\hline \multicolumn{2}{|l|}{$F$ - plantations of geographically alien trees $(N=13$ species $)$} \\
\hline Adenochilus gracilis Hook. f. & Abernethy, 1996 \\
\hline Cephalanthera longifolia (L.) Fritsch & Jakubska et al., 2006; Oklejewicz K, personal communication \\
\hline Chiloglottis cornuta Hook.f. & Abernethy, 1996 \\
\hline Dactylorhiza fuchsii (Druce) Soó & Oklejewicz $\mathrm{K}$, personal communication \\
\hline Dactylorhiza majalis (Rchb.) P.F. Hunt et Summerh. & Oklejewicz K, personal communication \\
\hline Dactylorhiza $x$ braunii Halacsy & Oklejewicz K, personal communication \\
\hline Epipactis helleborine (L.) Crantz & $\begin{array}{l}\text { Geisselbrecht-Taferner and Mucina, 1995; Sauerl, 1995; Soczewka, 2000; } \\
\text { Jakubska } \text { et al., } 2006 \text {; Kirpluk I, personal communication }\end{array}$ \\
\hline Epipactispalustris (L.) Crantz & Oklejewicz K, personal communications \\
\hline
\end{tabular}


130

Goodyera repens (L.) R. Br.

Listera ovata (L.) R. Br.

Malaxis monophyllos (L.) Sw.

Platanthera bifolia (L.) Rich.

Platanthera chlorantha (Custer) Rchb.

G - roadsides and embankments $(\mathrm{N}=35$ species $)$

Cephalanthera damasonium (Mill.) Druce

Cephalanthera rubra (L.) Rich.

Cypripedium acaule Aiton

Cypripedium calceolus $\mathrm{L}$.

Dactylorbiza fuchsii (Druce) Soó

Dactylorhiza incarnata (L.) Soó

Dactylorbiza maculata (L.) Soó

Dactylorhiza majalis (Rchb.) P.F. Hunt et Summerh.

Dactylorhiza $\times$ braunii Halacsy

Diphylax griffithii (Hook.f.) Kraenzl.

Dipodium roseum D.L. Jones and M.A. Clem.

Epipactis atrorubens (Hoffm.) Besser

Epipactis helleborine (L.) Crantz

Epipactis palustris (L.) Crantz

Epipactis $\times$ schmalhausenii K.Richter

Eulophia sinensis Miq

Gymnadenia conopsea (L.) R. Brsubsp. conopsea

Gymnadenia conopsea (L.) R. Br.

subsp. densiflora (Wahlenb.) K. Richt.

Herminium monorchis (L.) R.Br.

Liparis loeselii (L.) Rich.

Listera ovata (L.) R. Br.

Malaxis monophyllos (L.) Sw.

Neottia nidus-avis (L.) L.C.M.Rich

Neottianthe cucullata (L.) Schltr.

Ophrys apifera Huds.

Ophrys insectifera L.

Orchis militaris L.

Platanthera bifolia (L.) Rich.

Platanthera chlorantha (Custer) Rchb.

Spiranthes cernua (L.) Rich.

Spiranthes gracilis (Blume) Hassk.

Spiranthes hongkongensis S.Y.Hu and Barretto

Spiranthes lucida (H. H. Eaton) Ames

Spiranthes spiralis (L.) Chevall.

Spiranthes vernalis Engelm. and A.Gray

Zeuxine strateumatica (Linnaeus) Schlechter

$\mathrm{H}$ - sand pits, clay pits and quarries $(\mathrm{N}=\mathbf{4 8}$ species)

Anacamptis pyramidalis (L.) Rich.

Cephalanthera damasonium (Mill.) Druce

Cephalanthera longifolia (L.) Fritsch

Cephalanthera rubra (L.) Rich.

Coeloglossum viride (L.) Hartm.

Corallorbiza trifida Châtel.

Cypripedium calceolus L.

Dactylorhiza fuchsii (Druce) Soó

Dactylorhiza incarnata (L.) Soó

Dactylorhiza maculata (L.) Soó

Dactylorhiza majalis (Rchb.) P.F. Hunt et Summerh.
Adamowski W, unpubl.

Adamowski, 1996, 1998; Oklejewicz K, personal communication

Oklejewicz K, personal communication

Adamowski, 1996, 1998; Oklejewicz K, personal communication

Rutkowski L, personal communication

Bernacki and Błońska, 2006

Adamowski, 1996, 1998

Stuckey, 1967

Case, 1987

Tabaka et al., 1988; Adamowski, 1996, 1998; Bernacki and Błońska, 2006

Tabaka et al., 1988

Adamowski, 1996, 1998; Nissalo M, correspondence

Hereźniak and Pierzgalski, 1991; Adamowski, 1996, 1998; Bernacki and

Błońska, 2006

Adamowski, 1996, 1998

Renz et al., 1984

Jolly, 1998

Piotrowska, 1966; Nikolaeva and Zefirov, 1971; Wika, 1986; Šalak and Dvorak, 1989; Adamowski, 1996, 1998; Nowak, 1997; Bernacki and Błońska, 2006

Piotrowska, 1966; Ćwikliński, 1971; Nikolaeva and Zefirov, 1971; Renz, 1984;

Jackowiak, 1986; Wika, 1986; Berdowski and Spałek, 1997; Sudnik-

Wójcikowska, 1987; Szlachetko, 1988; Dickson, 1990; Stolarz, 1994;

Adamowski, 1996, 1998; Nowak, 1997; Urbisz and Urbisz, 1998; Soczewka,

2000; Bernacki and Błońska, 2006; Dengubenko A.V., personal communication

Hereźniak and Pierzgalski, 1991; Nowak, 1997; Wyrzykiewicz-Raszewska et al.,

2001; Bernacki and Błońska, 2006; Nissalo M., correspondence

Adamowski, 1996, 1998; Nowak, 1997

Sun, 1997

Bernacki and Błońska, 2006

Bernacki and Błońska, 2006

Renz, 1984

Stuckey, 1967; Case, 1987

Kovalevskaja, 1971; Jehlík, 1986; Berdowski and Spałek, 1997; Nowak, 1997;

Urbisz and Urbisz, 1998; Bernacki and Błońska, 2006

Bernacki and Błońska, 2006

Adamowski, 1996, 1998; Nowak, 1997

Adamowski, 1996, 1998

Wells and Cox, 1991

Bernacki and Błońska, 2006

Berezutsky et al., 2014

Berdowski and Spałek 1997; Adamowski 1996, 1998; Bernacki and Błońska 2006

Adamowski, 1996, 1998

Stuckey, 1967

Stuckey, 1967

Sun, 1997

Case, 1987

Sinker et al., 1991

Stuckey, 1967

Sun, 1997

Sinker et al., 1991; Heyde and Krug, 2000

Koszela and Sarosiek, 1985; Heyde and Krug, 2000

Koszela and Sarosiek, 1985

Droz, 1994; Heyde and Krug, 2000

Sinker et al., 1991

Heyde and Krug, 2000

Case, 1987; Heyde and Krug, 2000

Sinker et al.1991; Heyde and Krug, 2000

Heyde and Krug, 2000

Koszela and Sarosiek, 1985; Heyde and Krug, 2000; Czylok et al., 2008

Heyde and Krug, 2000; Czylok et al., 2008 
Dactylorhiza praetermissa (Druce) Soó

Epipactis atrorubens (Hoffm.) Besser

Epipactis helleborine (L.) Crantz

Epipactispalustris (L.) Crantz

Gymnadenia conopsea (L.) R.Br.

Gymnadenia conopsea (L.) R. Br subsp. conopsea

Habenaria linguella Lindl.

Liparisloeselii (L.) Rich.

Listera ovata (L.) R. Br.

Malaxis monophyllos (L.) Sw.

Neottia nidus-avis (L.) L.C.M.Rich

Ophrys apifera Huds.

Ophrys bombyliflora Link

Ophrys ciliata Link

Ophrys garganica O.Danesch and E.Danesch

Ophrys incubacea Bianca

Ophrys sphegodes Mill.

Ophrys tenthredinifera Willd.

Ophrys $\times$ grampini Cortesi

Ophrys $\times$ hoeppneri Rupper

Ophrys $\times$ macchiatincubacea

Orchis coriophora $\mathrm{L}$.

Orchis laxiflora (Lam.) R.M. Bateman, Pridgeon and M.W. Chase

Orchis mascula L.

Orchis militaris L.

Orchis morio L.

Orchis papilionacea L.

Platanthera bifolia (L.) Rich.

Platanthera chlorantha (Custer) Rchb.

Serapias lingua L.

Serapias parviflora Parl.

Serapias vomeracea (Burm.f.) Briq.

Spiranthes lucida (H.H. Eaton) Ames

Spiranthes sinensis (Pers.) Ames

Spiranthes spiralis (L.) Chevall.

Zeuxine strateumatica (Linnaeus) Schlechter
Sinker et al., 1991

Koszela and Sarosiek, 1985; Forman et al., 2003; Droz 1994; Heyde and Krug, 2000; Czylok et al. 2008;

Koszela and Sarosiek, 1985; Heyde and Krug, 2000; Czylok et al., 2008

Droz, 1994; Mróz and Rudecki, 1995; Berdowski and Spałek, 1997; Chau and Siu, 1998; Heyde and Krug, 2000; Nowak and Witkowska, 2006; Czylok et al., 2008; Maciejewska-Rutkowska et al., 2008; Błońska, 2010

Koszela and Sarosiek, 1985

Droz, 1994; Heyde and Krug, 2000

Chau and Siu, 1998

Case, 1987; Heyde and Krug, 2000; Bzdon and Ciosek, 2006; Czylok et al., 2008; Błońska, 2010

Koszela and Sarosiek, 1985; Farrell, 1991; Heyde and Krug, 2000; Czylok et al., 2008

Czylok et al., 2008

Sinker et al., 1991; Koszela and Sarosiek, 1985; Heyde and Krug, 2000

Rossi, 1989; Sinker et al., 1991; Wells and Cox, 1991; Heyde and Krug, 2000

Rossi, 1989

Rossi, 1989

Rossi, 1989

Rossi, 1989

Rossi, 1989

Rossi, 1989

Rossi, 1989

Rossi, 1989

Rossi, 1989

Rossi, 1989

Rossi, 1989

Koszela and Sarosiek, 1985

Farrell, 1991; Heyde and Krug, 2000

Rossi, 1989

Rossi, 1989

Koszela and Sarosiek, 1985; Kukułczanka et al., 1985; Heyde and Krug, 2000

Sinker et al., 1991; Heyde and Krug, 2000

Rossi, 1989

Rossi, 1989

Rossi, 1989

Case, 1987

Chau and Siu, 1998

Rossi, 1989

Chau and Siu, 1998 include representatives of the genus Epipactis (mainly $E$. helleborine, E. atrorubens, E. palustris) and the genus Dactylorhiza (D. majalis, D. fuschii and D. maculata). Also, according to other authors, these orchids are the most frequently subjected to apophytisation (Dickson, 1990; Farrell, 1991; Ehlers et al., 2002; Bernacki and Błońska, 2006; Wittig and Wittig, 2007; Akhalkatsi et al., 2014). Among the aforementioned species, the most frequently reported in disturbed habitats was $E$. helleborine, which may be a result of its wide ecological amplitude, wide range of mycorrhizal spectrum with a fungal component, phenotypic plasticity and a considerable group of optional pollinators (Dickson, 1990; McCormick et al., 2004; Selosse et al., 2004; Rewicz et al., 2016).

The analysis of the available data has shown that populations of some species remain on anthropogenic habitats for several years, hence they can be called euapophytes (apophytes sensu stricto, i.e. permanently established in anthropogenic habitats) (Jackowiak, 2006). The same phenomenon was confirmed in the studies conducted by
Adamowski and Conti (1991) and Adamowski (2006) on Epipactis helleborine and Platanthera bifolia growing in poplar plantations. Their observations show that populations of these orchids have remained in disturbed habitats for up to 25 years. Similar results were obtained by Light and MacConaill (2005, 2006) on Epipactis helleborine, and also by Stark (2010) on Gymnadenia conopsea, and Wyrzykiewicz-Raszewska et al. (2001) on Epipactis palustris.

Anthropogenic habitats not only become refugia for species considered to be rare or even endangered, but often have an impact on the phenotypic plasticity of their specimens, as well as demographics and the life story of entire populations. Quintana-Ascencio et al. (2007) has proven that populations of endemic species of Hypericum cumulicola from Florida growing in disturbed populations are characterised by shorter life length, faster growth and earlier production of seeds while compared to natural populations. Similar conclusions concerning phenotypic variation and maintaining the population of Epipactis helleborine on roadsides were drawn by Rewicz (2015, unpublished data) and Rewicz et al. (2016). 
132

Table 3. Orchids species noted in analyzed cities

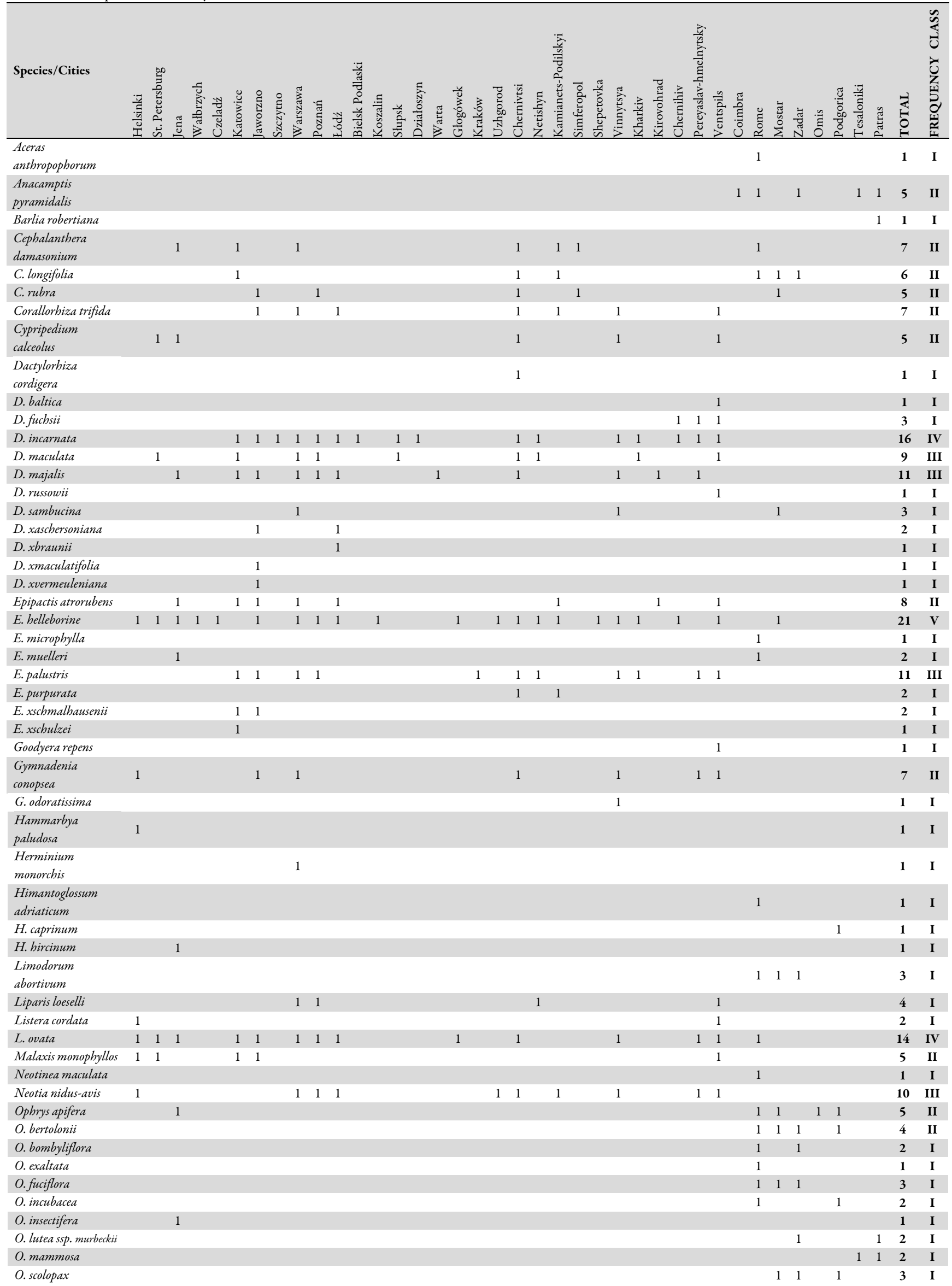




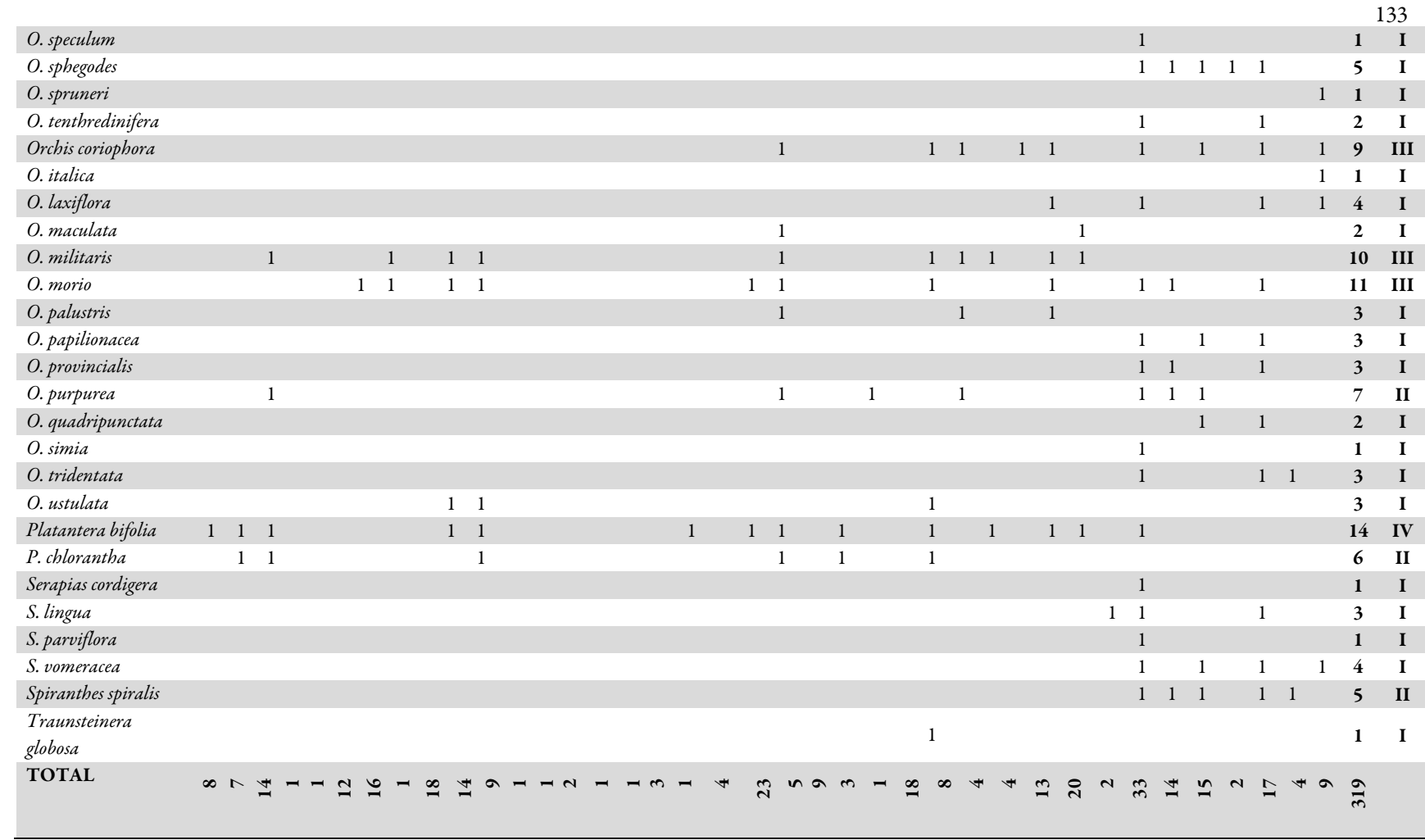

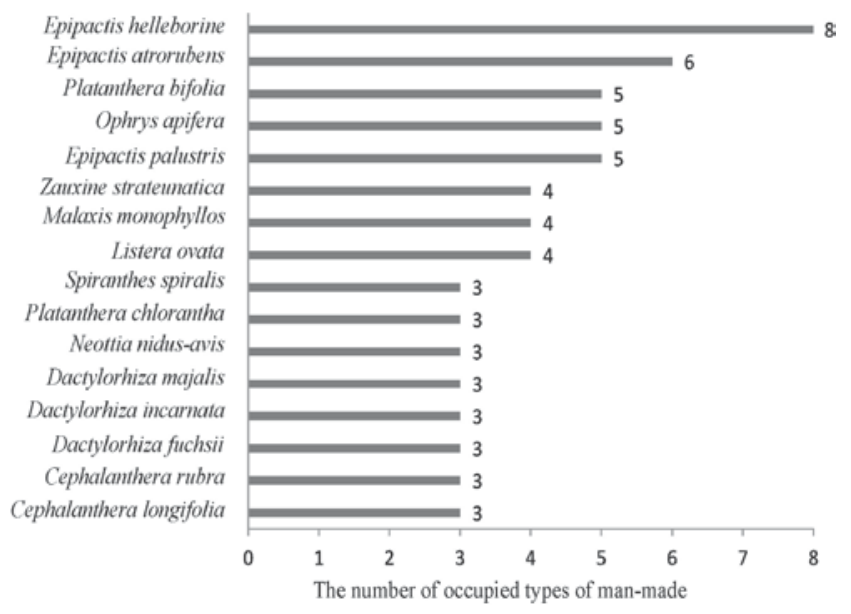

Fig. 1. The most common orchid species in various distinguished types of man-made habitats

Orchid species composition in anthropogenic habitats is a reflection of the species composition in the adjacent habitats, as well as of the geographical range of plants. Thus, it can explain the presence of the species from the genus Dactylorbiza and Epipactis in Eastern Europe, and the occurrence of the species from the genus Serapias and Ophrys in Western Europe. In the analysis of orchid occurrence in particular cities, it has also been observed that in Central European cities the species mentioned above dominate, while in the group of Balkan towns the species of the genus Ophrys and Serapias are dominant. This is due to the geographical ranges of the analysed taxa and the number of urban areas within the given part of Europe. In the case of the Balkans, the species of the Ophrys or Serapias genus are much more abundant, while in Central Europe and in the Ukraine those species do not occur (Delforge, 2006).

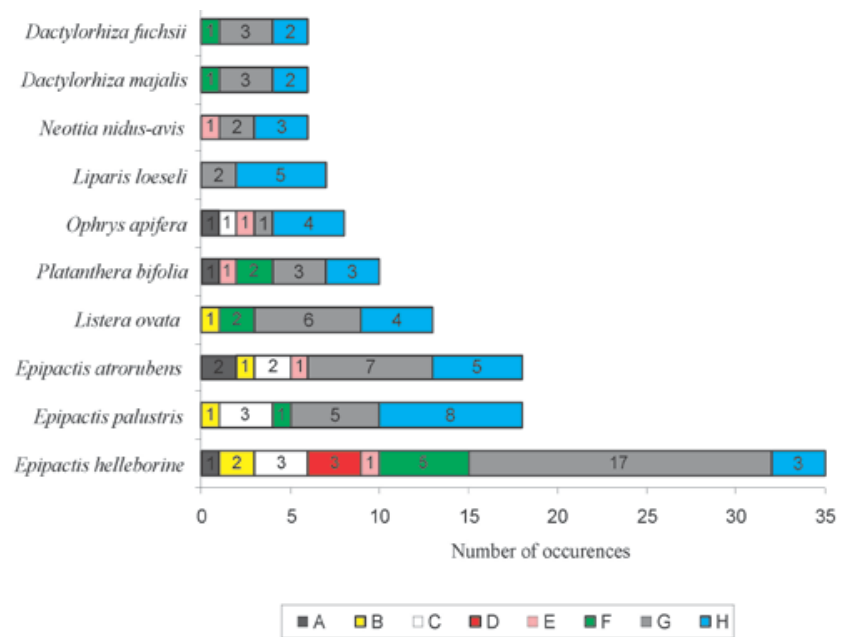

Fig. 2. The most frequently orchid species in the distinguished types of man-made habitats. (A) forests influenced by industrial emissions; (B) industrial terrains; (C) industrial waste places; (D) parks, hedges etc. greenery; (E) plantations of ecologically alien trees; (F) plantations of non-native trees; $(G)$ roadsides and embankments; $(\mathrm{H})$ sand pits, clay pits and quarries

Such a great number of orchid species in various anthropogenic habitats poses the question as to whether manmade habitats are an "ecological equivalent" to naturally occurring habitats. It is pointed out that anthropogenic sites can be considered as temporary shelters, rather than mainstays, from which plants can expand further. Frequently, these refugia play the role of corridors for expansion of species and links between natural populations (Nowak and Nowak 2006; Esfeld et al., 2008; van Kleef et al., 2012). 


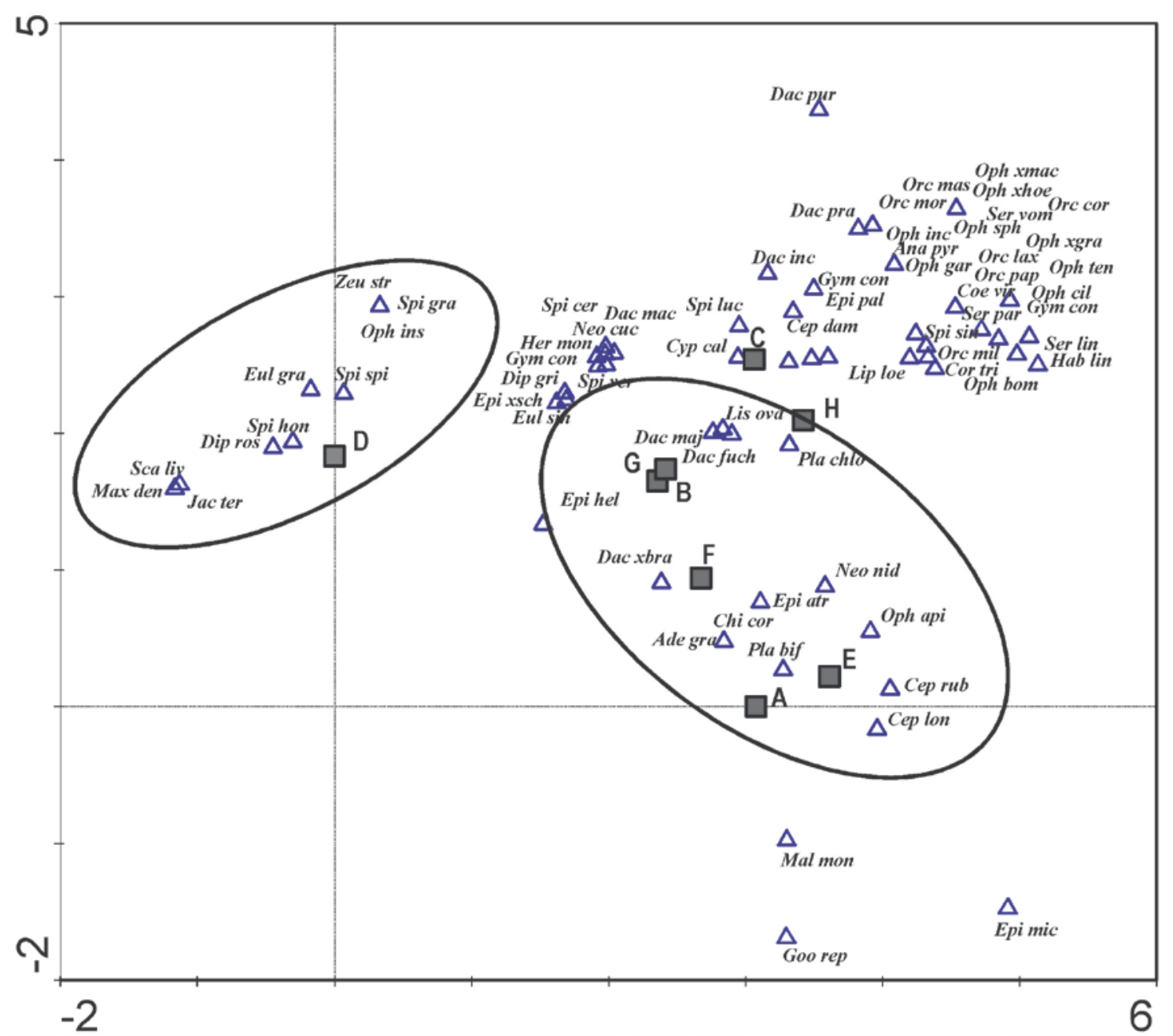

Fig. 3. Ordination diagram based on Detrended Correspondence Analysis (DCA) showing connection of orchid species to the different types of man-made habitats. A, B... H - distinguished types/kinds of man-made habitats, see Fig. 2

The prevalence of orchids and other valuable plants in anthropogenic habitats should draw attention to the problem of maintaining rare and endangered species in non-natural ecological systems (van Kleef et al., 2012; Zielińska et al., 2016). Although currently there is no literature data about species conservation carried out in populations of orchids in anthropogenic habitats, such populations should be observed in terms of their condition and stability.

Furthermore, occurrence of orchids in anthropogenic habitats provides an opportunity to use those populations in the educational process. Very often, those species are protected by law, hence it is possible to make some nature trails and organise outdoor lessons, enhancing nature conservation knowledge.

\section{Conclusions}

The conducted review has shown that some man-made and disturbed habitats host many rare orchids and could provide a chance for survival of those rare and valuable plant species. The need for the protection of sites of valuable orchid species in habitats strongly transformed by man should be taken into consideration at the present time.

\section{Acknowledgements}

The authors would like to thank the following for sharing information: Dr. Wojciech Adamowski from Białowieża Geobotanical Station of Warsaw University and Prof. Zbigniew Sobisz from Pomeranian University in Stupsk. This study was financially supported by the internal funds of the Department of Geobotany and Plant Ecology, University of Lodz.

\section{References}

Abernethy A (1996). The role of light availability on terrestrial native orchids in exotic plantations. $\mathrm{PhD}$ Thesis, University of Canterbury, Canterbury.

Adamowski W (1996). Apofityzm wybranych gatunków storczykowatych (Orchidaceae) i jego uwarunkowania ekologiczne [Apophytism of chosen species of Orchidaceae and its ecological conditions]. $\mathrm{PhD}$ Thesis, Warsaw University, Warszawa.

Adamowski W (1998). Colonization success of orchids in disturbed habitats. In: Falińska K (Ed). Plant population biology and vegetation processes. Institute of Botany PAS, Kraków pp 165-172. 
Adamowski W (2002). Expansion of native orchid species. In: Faliński JB (Ed). Białowieża Geobotanical Station of Warsaw Uniwersity. Long-term studies. Bibliography. Data basis on the vegetation and environment 1952-2002. Phytocoenosis 14 (NS) Supplementum Cartographicae Geobotanicae 5:111-113.

Adamowski W (2006). Expansion of native orchids in anthropogenous habitats. Polish Botanical Studies 22:35-44.

Adamowski W, Conti F (1991). Masowe występowanie storczyków na plantacjach topolowych pod Czeremchą jako przykład apofityzmu [Mass occurrence of orchids in poplar plantations near Czeremcha village as an example of apophytism]. Phytocoenosis 3:259-267.

Akhalkatsi M, Arabuli G, Lorenz R (2014). Orchids as indicator species of forest disturbances on limestone quarry in Georgia (South Caucasus).Journal Europäischer Orchideen 46(1):123-160.

Andrews A (1990). Fragmentation of habitat by roads and utility corridors: a review. Australian Zoologist 26(3-4):130-141.

Arkushyna GF, Popova OM (2010). Checklist of vascular plants of Kirovograd. Polimer-Servis Press, Kirovograd.

Barrico L, Azul AM, Morais MC, Coutinho AP, Freitas H, Castro P (2012). Biodiversity in urban ecosystems: Plants and macromycetes as indicators for conservation planning in the city of Coimbra (Portugal). Landscape and Urban Planning 106(1):88-102.

Berdowski W, Spałek K (1997). Rozmieszczenie oraz zasoby chronionych gatunków roślin naczyniowych we wschodniej części województwa opolskiego [Distribution of resources and protected species of vascular plants in the eastern part of the province of Opole]. Acta Universitatis Wratislaviensis 1936, Prace Botaniczne 73:7-26.

Berezutsky MA, Reshetnikova TB, Serova LA, Kashin AS (2014). Ecological despecialization of species of the family Orchidaceae Juss. in the North of the Lower-Volga region. Biology Bulletin 41(10):849-850.

Bernacki L (1987). Microstylis monophyllos (L.) Lindley im Oberschlesischen Industriegebiet und in den angrenzenden Teritorien. Kulturbund, Berlin 16:38-43.

Bernacki L, Błońska A (2006). Występowanie storczykowatych (Orchidaceae) w otoczeniu południowego odcinka drogi KrośnicaNiedzica w Pienińskim Parku Narodowym [Occurrence of orchids (Orchidaceae) in the vicinity of the southern section of KrośnicaNiedzica road in the Pieniny National Park]. Pieniny - Przyroda i Człowiek 9:65-70.

Bilz M, Kell SP, Maxted N, Lansdown RV (2011). European Red List of Vascular Plants. Publications Office of the European Union, Luxembourg.

Błońska A (2010). Siedliska antropogeniczne na Wyżynie Śląskiej jako miejsca występowania rzadkich i zagrożonych gatunków torfowiskowych klasy Scheuchzerio-Caricetea nigrae (Nordh. 1937) R. Tx 1937 [Anthropogenic sites on Silesian Upland as the habitats of rare and endangered marsh species of the ScheuchzerioCaricetea nigrae (Nordh. 1937) R. Tx 1937]. Woda-ŚrodowiskoObszary Wiejskie 1(29):7-19.

Brändle M, Durka W, Krug H, Brandl R (2003). The assembly of local communities: Plants and birds in non-reclaimed mining sites. Ecography 26:652-660.
Bróż E, Maciejczak B (1991). Niektóre nowe oraz rzadkie i zagrożone gatunki roślin naczyniowych we florze miasta i strefy podmiejkiej Kielc [Some new and rare and endangered species of vascular plants in the flora of the city and the suburban area of Kielce]. Fragmenta Floristica et Geobotanica 36(1):171-179.

Brun C (2009). Biodiversity changes in highly anthropogenic environments (cultivated and ruderal) since the Neolithic in eastern France. The Holocene 19(6):861-871.

Burda RI (1998). Examples of invasion by threatened native species in anthropogenous ecotopes. In: Starfinger U, Edwards K, Kowarik I, Williamson M (Eds). Plant invasions: Ecological mechanisms and human responses. Backhuys Publishers, Leiden pp 299-306.

Bzdon G, Ciosek MT (2006). Fen orchid Liparis loeselii (L.) Rich. in abandoned gravel-pit in Dąbrówka Stany near Siedlce (Poland). Biodiversity: Research and Conservation 1(2):193-195.

Case FW (1987). Orchids of the Western Great Lakes Region. Cranbrook Institute of Science Bulletin 48, Bloomfield Hills, Michigan.

Celesti-Grapow L, Capotorti G, Del Vico E, Lattanzi E, Tilia A, Blasi C (2013). The vascular flora of Rome. Plant Biosystems 147(4):10591087.

Chau L, Siu G (1998). Orchid on ash. Retrieved 2015 Nov 25 from http://www.biosch.hku.hk/ecology/porcupine/por17/flora.htm.

Chronopoulos G, Christodoulakis D (1996). Contribution to the urban ecology of Greece: the flora of the city of Patras and the surrounding area. Botanica Helvetica 106:159-176.

Conti F (1987). S.O.S. Pineta d'Avalos, scomparsa per sempre una rarissima e bella orchidea [S.O.S. Pineta d'Avalos, disappeared forever a very rare and beautiful orchid]. Panda 21(3):5.

Ćwikliński E (1971). Flora synantropijna Zielonej Góry i Koszalina na tle warunków przyrodniczych i rozwoju miast [Synanthropic flora of the Zielonej Mountainsand Koszalin against natural conditions and urban development]. Materiały Zakładu Fitosociologi Stosowanej UW 27:81-113.

Czylok A, Rahmonov O, Szymczyk A (2008). Biological diversity in the area of quarries after sand exploitation in the eastern part of Silesian Upland. Teka. Komisji Ochrony i Kształtowania Środowiska Przyrodniczego OL PAN 5A:15-22.

Davis BNK (1979). Chalk and limestone quarries as wildlife habitats. Minerals and the Environment 1:48-56.

Delforge P (2006). Orchids of Europe, Nord Africa and the Middle East. A and C Black Publishers, London.

Dickson JH (1990). Epipactis helleborine in gardens and other urban habitats: an example for apophytism. In: Sukopp H, Hejny S (Eds). Urban ecology. SPB Academic Publishing, The Hague pp 245249.

Droz J (1994). La végétation de la région de Derborence (Conthey, Chamoson, Valais) [The vegetation of the area of Derborence (Conthey, Chamoson, Valais)]. Geobotanica Helvetica70:1-239.

Efimov PG (2011). Revealing the decline and expansion of orchids of NW European Russia. The European Journal of Environmental Sciences 1(2):7-17.

Ehlers BK, Olesen JM, Gren JG (2002). Floral morphology and reproductive success in the orchid Epipactis helleborine: regional and 
136

local across-habitat variation. Plant Systematics and Evolution 236(1/2):19-32.

Esfeld K, Hensen I, Wesche K, Jakob SS, Tischew S, Blattner FR (2008). Molecular data indicate multiple independent colonizations of former lignite mining areas in Eastern Germany by Epipactis palustris (Orchidaceae). Biodiversity and Conservation 17:24412453.

Farrell L (1991). Population changes and management of Orchis militaris at two sites in England. In: Wells TCE, Willems JH (Eds). Population ecology of terrestrial orchids. SPB Academic Publishing, The Hague pp 63-68.

Forman RTT, Sperling D, Bissonette J, Clevenger AP, Cutshall C, ... Winter T (2003). Road Ecology: Science and Solutions. Island Press.

Geisselbrecht-Taferner L, Mucina L (1995). Vegetation der Brachen am Beispiel der Stadt Linz [Vegetation of industries based on the city Linz].Stapfia 38:1-151.

Geisselbrecht-Taferner L, Mucina L (1993). Bidentetea tripartite. In: Mucina L, Grabherr G, Ellmauer T (Hrsg.) Die Pflanzengesellschaften Osterreichs. Teil 1. Antropogene Vegetation. Jena - Stuttgart - New-York: Gustav Fischer Verlag pp 91-109.

Godefroid S (1995). Epipactis helleborine en extension à Bruxelles [Epipactis helleborine extended in Brussels]. Adoxa 6/7:13-14.

Greenwood EF, Gemmell RP (1978). Derelict industrial land as a habitat for rare plants in S. Lancs. (v.c. 59) and W. Lancs. (v.c. 60). Watsonia 12:33-40.

Gubar LM (2006). Urban floras of the Eastern part of Middle Polissya (case stydies of the Ostraog, Netishyn, Slavuta, and Shepetivka). PhD Thesis, M.G. Kholodny Institute of Botany of the National Academy of Sciences of Ukraine, Kyiv.

Gutsmam A (2013). Flora in the cities of the Eastern part of Volyn' Region. Dissertation, M.G. Kholodny Institute of Botany of the National Academy of Sciences of Ukraine, Kyiv.

Heindl B, Ullmann I (1991). Roadside vegetation in Mediterranean France. Phytocoenologia 20:111-141.

Heinrich W, Dietrich H (2008). Heimische Orchideen in urbanen Biotopen [Native orchids in urban habitats]. Feddes Repert 119(56):388-432.

Hereźniak J, Pierzgalski K (1991). Stanowiska rzadkich i chronionych gatunków roślin łąkowych na terenie Częstochowy [Localities of rare and protected species of meadow plants in Częstochowa]. Chrońmy Przyrodę Ojczystą 47(3):79-84.

Heyde K, Krug H (2000). Orchideen in der Mitteldeutschen Braunkohlen-Bergbaufolgelandschaft. LMBV Lausitzer und Mitteldeutsche Bergbau-Verwaltungsgesellschaft mbH, Espenhain.

Hollingsworth PM, Dickson JH (1997). Genetic variation in rural and urban populations of Epipactis helleborine (Orchidaceae) in Britain. Botanical Journal of the Linnean Society 123:321-331.

Iepikhin DV (2008). Current state of Simferopol vegetative cover. Dissertation, University of Yalta.

Ignatieva M, Konechnaya G (2004). Floristic Investigations of Historical Parks in St. Petersburg, Russia. Urban Habitats 2(1):174216.
Jackowiak B (1986). Dynamika synantropizacji flory Poznania jako rezultat antropogenicznych zmian w ekosystemie dużego miasta [Dynamics synanthropisation flora of Poznan as a result of anthropogenic changes in the ecosystem of a big city]. Part 2. Wykaz i charakterystyka roślin naczyniowych Poznania, Adam Mickiewicz University, Poznań.

Jackowiak B (1993). Atlas rozmieszczenia roślin naczyniowych w Poznaniu. Prace Zakładu Taksonomii Roślin [Atlas of distribution of vascular plants in Poznań]. UAW, Poznań.

Jackowiak B (2006). Methodological proposals for studies on the structure and dynamics of urban flora. Polish Botanical Studies 22:251-260

Jakubska A, Malicka M, Malicki M (2006). New data on the apophytic occurrence of Epipactis helleborine (L.) Crantz and Cephalanthera longifolia (L.) Fritsch in Populus $\times$ canadensis plantation in Lower Silesia (south-western Poland). Biodiversity: Research and Conservation 1(2):96-98.

Jehlik V (1986). The vegetation of railways in northern Bohemia (eastern part). Vegetace ČSSR, Ser A,14. Academia, Praha pp 1366.

Jolly K (1998). Dipodium roseum field trip. Retrieved 2015 Nov 25 from http://www.anos.org.au/groups/southaustralia/nossa-c.html.

Jongman RHG (2002). Homogenisation and fragmentation of the European landscape: ecological consequences and solutions. Landscape and Urban Planning 58:211-221.

Jurkiewicz A, Turnau K, Mesjasz-Przybyłowicz J, Przybyłowicz W, Godzik B (2001). Heavy metal localisation in mycorrhizas of Epipactis atrorubens(Hoffm.) Besser (Orchidaceae) from zinc mine tailings. Protoplasma 218:117-124.

Kirpluk I, Bomanowska A (2008). Rare, endangered and protected plant species of synanthropic flora of the Kampinos National Park (Central Poland). Biodiversity: Research and Conservation 11(12):71-80.

Klimko M, Czarna A, Bałuka B (2004). Vascular plants of postindustrial habitats in Watbrzych city. Acta Botanica Silesiaca 1:7-22.

Korzhan KV (2011). Systematic structure of Chernivtsi urban flora. Ukrainian Botanical Journal 68(3):388-393.

Koszela M, Sarosiek J (1985). The stone quarry at Nowe Rochowice near Bolków in Lower Silesia. Chrońmy Przyrodę Ojczystą 41(4):64-70.

Kotsur VP, Dzhuran VM, Fedoronchuk MM, Shevera MV (2010). Pereyaslav-Khmelnytsky. Nature - Plant Kingdom. M.G. Kholodny Institute of Botany of the National Academy of Sciences of Ukraine, Kyiv.

Kovalevskaja SS (1971). Opredelitel rastenij Sredniej Azii. Kriticeskij konspekt flory II. Izdatelstvo Fan UzbekskojSSR, Taškent.

Kowarik I (1991). The adaptation of urban flora to man-made perturbations. In: Ravera $\mathrm{O}(\mathrm{Ed})$. Terrestrial and aquatic ecosystems: perturbation and recovery. Ellis Horwood, London pp 176-184.

Krigas N, Kokkini S (2005). Indigenous vascular flora of the urban and suburban area of Thessaloniki (N Greece). Botanika Chronika 18(2):29-85. 
Kukułczanka K, Sarosiek J, Wiewiórka Z, Wożakowska-Natkaniec H (1985). Platanthera bifolia (L.) Richard on the secondary habitat in a claypit near Malayce, Lower Silesia. Proceedings of the Symposium on Biology and Ecology of European Orchids. Karpacz, Poland pp 103-109.

Latzel L, Klimešová J, Doležal J, Pyšek P, Tackenberg O, Prach K (2011). The association of dispersal and persistence traits of plants with different stages of succession in Central European man-made habitats. Folia Geobotanica 46:289-302.

Leps J, Smilauer P (2003). Multivariate analysis of ecological data using CANOCO. Cambridge Univ Press, Cambridge pp 12-69.

Levanets AA, Shevera MV, Manturova OV, Kahala OV (2004). Biodiversity of Kamyanets-Podilskyi: preliminary critical inventarisation checklist of plants, fungi and animals. Liha-Pres, Lviv.

Light MHS, MacConaill M (2005). Long-term studies: a case for orchid species survival. Selbyana 26:174-188.

Light MHS, MacConaill M (2006). Appearance and disappearance of a weedy orchid, Epipactis helleborine. Folia Geobotica 41:77-93.

Lundholm JT, Richardson PJ (2010). Habitat analogues for reconciliation ecology in urban and industrial environments. Journal of Applied Ecology 47:966-975.

Maciejewska-Rutkowska I, Rutkowski P, Kluza-Wieloch M, Andrzejewska M (2008). Population of Epipactis palustris (L.) Crantz (Orchidaceae) and its participation in local plant communities within the ecological useland "Kopanina I" in Poznań city. Botanica Steciana 12:45-51.

Maslo S (2014). The urban flora of the city of Mostar (Bosnia and Herzegovina). Natura Croatica 23(1):101-145.

McCormick MK, Whigham DF, O’Neill J (2004). Mycorrhizal diversity in photosynthetic terrestrial orchids. New Phytologist 163:425-438.

Milović M, Mitić B (2012). The urban flora of the city of Zadar (Dalmatia, Croatia). Natura Croatica 21(1):65-100.

MisiewiczJ (1976). Flora synantropijna i zbiorowiska ruderalne polskich portów morskich [Synanthropic flora and ruderal communities of Polish seaports]. WSP, Stupsk.

Misiewicz J (1978). Flora synantropijna Słupska na tle warunków przyrodniczych i rozwoju miasta [Flora synanthropic of Slupskon the background of natural conditions and development of the city]. WSP, Słupsk.

Mróz L, Rudecki AL (1995). Występowanie i warunki ekologiczne Epipactis palustris (L.) Cr. w kamieniołomie przy cementowni "Odra" w Opolu [Occurrence and ecological conditions of Epipactis palustris (L.) Cr. in the quarry at a cement plant "Odra" in Opole]. Acta Universitatis Wratislaviensis1717, Prace Botaniczne 63:101111.

Niedrist G, Tasser E, Lüth C, Dalla Via J, Tappeiner U(2009). Plant diversity declines with recent land use changes in European Alps. Plant Ecology 202:195-210.

Nikolaeva VM, Zefirov BM (1971). Flora Belovezhskoi pushchi (sosudistye sporovye i semennye rasteniya). Izdatelstvo Uradzhai, Minsk.
Nowak A (2005). Anthropogenic habitats as sites of occurrence of endangered, rare and protected plants on the example of Opole Silesia, SW Poland. Thaiszia Journal of Botany 15:155-172.

Nowak A (2006). Assessment of the Vascular Flora Conservation Through Specific Indices - A Comparison Study in Central Europe. Nature Conservation, series Environmental Science and Engineering pp 98-106.

Nowak A, Nowak S (2006). Anthropogenic Habitats Can Shelter Threatened Plants. Nature Conservation, series Environmental Science and Engineering pp 107-115.

Nowak K, Witkowska E (2006). Kruszczyk błotny Epipactis palustris (L.) Crantz na terenie wyrobiska „Cegielni Gnaszyn” w Częstochowie [Epipactis palustris (L.) CRANTZ on the exploitation hollow of the "Brickwork Gnaszyn" in Częstochowa]. Chrońmy Przyrodę Ojczystą 62(5):36-39.

Nowak T (1997). Flora synantropijna linii kolejowej Dąbrowa Górnicza - Strzemieszyce - Olkusz [Flora synanthropic of railway in Dąbrowa Górnicza - Strzemieszyce - Olkusz]. Acta Biologica Silesiaca 30(47):86-105.

Pedersen H, Watthana S, Srimuang KO (2013). Orchids in the torrent: on the circumscription, conservation and rheophytic habit of Epipactis flava. Botanical Journal of the Linnean Society 172:358370.

Pfeifer M, Jetschke G (2006). Influence of geographical isolation on genetic diversity of Himantoglossum hircinum (Orchidaceae). Folia Geobotanica 41:3-20.

Piekarska-Stachowiak A, Szary M, Ziemer B, Besenyei L, Woźniak G (2014). An application of the plant functional group concept to restoration practice on coal mine spoil heaps. Ecological Research 29:843-853

Piotrowska H (1966). Rośliny naczyniowe wysp Wolina i południowowschodniego Uznamu [Vascular Plants of the islands Wolin and south-eastern Usedom]. Prace Komisji Biologicznej Poznańskiego Towarzystwa Przyjaciół Nauki 30(4):1-282.

Procházka F, Velísek V (1983). Orchideje nasi prirody [Our nature orchids]. Ceskoslovenska Akademie, Prague.

Protopopova VV, Shevera MV (2002). A preliminary checklist of the urban flora of Uzhgorod. Phytosociocentre, Kyiv.

Quintana-Ascencio PF, Weekley CW, Menges ES (2007). Comparative demography of a rare species in Florida scrub and road habitats. Biological Conservation 137:263-270.

Rebele F (1988). Ergebnisse floristischer Untersuchungen in den Industriegebieten von Berlin (West) [Results of floristic studies in the industrial areas of Berlin]. Landschaft und Stadt 20(2):49-66.

Regulation of the Minister of Environment (2014). Regulation of 09 October 2014 with reference to the species of natural plants covered by protection. Polish Journal of Laws, item 1409 of 16 October 2014.

Reisch C (2006). Genetic structure of Saxifraga tridactylites (Saxifragaceae) from natural and man-made habitats. Conservation Genetics 8:893-902.

Remmel G (1970). Ungewöhnliche Epipactis-Formen auf der Halde eines alten Erzbergwerks [Epipactis in the old iron ore mine]. Journal ber Naturwiss Ver Wuppertal 23:119-122. 
138

Renz J, Ali S, Nasir E (1984). Flora of Pakistan. No. 164, Orchidaceae. University of Karachi, Karachi, Pakistan.

Rewicz A, Kołodziejek J, Jakubska-Busse A (2016). The role of anthropogenic habitats as substitutes for natural habitats: a case study on Epipactis helleborine (L.) Crantz (Orchidaceae, Neottieae). Variations in size and nutrient composition of seeds. Turkish Journal of Botany 40:258-268.

Rewicz A, Zielińska KM, Kiedrzyński M, Kucharski L (2015). Orchidaceae in the anthropogenic landscape of Central Poland: diversity, extinction and conservation perspectives. Archives of Biological Sciences Belgrade 67(1):119-130.

Rossi W (1989). Native orchids in the main archeological sites in Rome. Braun-Blanquetia 3:269-270.

Rostański A, Michalska M (2003). Obfite stanowisko kruszczyka błotnego (Epipactis palustris (L.) Crantz) na zwałowisku hutniczokopalnianym w Świętochłowicach - Chropaczowie (Górny Śląsk) [Rich population of orchid (Epipactis palustris (l.) Cranz) on a zinccolliery heap in Świętochłowice - Chiropaczów (Upper Silesia, Poland)]. Archiwum Ochrony Środowiska 29(2):115-118.

Šalak AI, Dvorak LE (1989). Redkie vidy orchidnych v Belovežskoj Pušče.Zapovedniki Belorussii 13:48-56.

Sauerland KE (1995). Orchideen in Rostocker Grünanlagen. Naturschutzarb. Mecklenburg-Vorpommern 35(2):53-54.

Selosse MA, Faccio A, Scappaticci G, Bonfante P (2004). Chlorophyllous and achlorophyllous specimens of Epipactis microphylla (Neottieae, Orchidaceae) are associated with ectomycorrhizal septomycetes, including truffle. Microbial Ecology $47(4): 416-426$.

Sharrock S, Jones M (2009). Conserving Europe's threatened plants: Progress towards Target 8 of the Global Strategy for Plant Conservation. Botanic Gardens Conservation International, Richmond, UK.

Sinker CA, Packham JR, Trueman IC, Oswald PH, Perring FH, Prestwood W (1991). Ecological flora of the Shropshire Region. Shropshire Wildlife Trust, Shrewsbury.

Siu G, Chau L (1998). Rescue of native orchids. Porcupine 17,7. Retrieved 2015 November 25 from http:// www. hku.hk/ecology/porcupine/por17/flora.htm.

Soczewka B (2000). New localities of rare vascular plant species in the Mesoregion of Łomaska Depression (eastern Poland). Fragmenta Floristica et Geobotanica 7:81-91.

Solis-Montero L, Flores-Palacios A, Cruz-Angón A (2005). ShadeCoffee Plantations as Refuges for Tropical Wild Orchids in Central Veracruz, Mexico. Conservation Biology 19(3):908-916.

StatSoft Inc (2013). Electronic Statistics Textbook. Tulsa, OK: StatSoft.

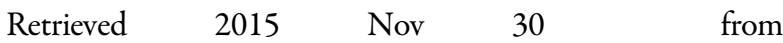
http://www.statsoft.com/textbook.

Stark C (2010). Population genetics on anthropogenic and natural sites, subspecies differentiation and fungal community of Gymnadenia conopsea s.l. (Orchidaceae) $\mathrm{PhD}$ Thesis, Philipps University Marburg.

Stefaniak A, Adamowski W, Święczkowska E, Jakubska-Busse A (2011). Zmiany liczebności i zagęszczenia populacji Epipactis belleborine (L.) Crantz (Orchidaceae) na siedlisku antropogenicznym w północno-wschodniej Polsce [Changes in the abundance and population density of Epipactis helleborine (L.) Crantz (Orchidaceae) in anthropogenic habitats in northeastern Poland]. Acta Botanica Silesiaca 7:189-196.

Stešević D, Caković D, Jovanović S (2014). The urban flora of Podgorica (Montenegro, SE Europe): annotated checklist, distribution atlas, habitats and life-forms, taxonomic, phytogeographical and ecological analysis. Ecologica Montenegrina, Supplementum 1:1-171.

Stolarz P (1994). Kruszczyk szerokolistny Epipactis latifolia na torowisku kolejki leśnej w lasach [Epipactis latifolia on guideway forest railway in okuniewsko-rembertowskich forest]. Chrońmy Przyrodę Ojczystą 50(5):73-74.

Stuckey IH (1967). Environmental factors and the growth of native orchids. American Journal of Botany 54:232-241.

Sudnik-Wójcikowska B (1987). Flora Warszawy i jej przemiany w ciagu XIX I XX wieku [Flora of the city of Warsaw and its transformation during the XIX and XX centuries]. Vol 1-2. UW, Warszawa.

Sukopp H (2006). Apophytes in the flora of Central Europe. Polish Botanical Studies 22:473-485.

Sukopp H (2008). Apophyten in der Flora von Mitteleuropa. Braunschweiger Geobotanische Arbeiten 9:443-458.

Sun M (1997). Genetic diversity in three colonizing orchids with contrasting mating systems. American Journal of Botany $84(2): 224-232$.

Suwara-Szmigielska $S$ (2010). Flora roślin naczyniowych małych miast zachodniej części województwa łódzkiego [Flora of vascular plants of small cities in the western part of the Lodz region]. Dissertation, University of Łódź, Łódź.

Środa M (2002). Materiały do flory roślin naczyniowych miasta Szczytna na Pojezierzu Mazurskim [Materials for the vascular flora of the town of Szczytna in the Pojezierzu Mazurskim]. Acta Botanica Warmiae et Masuriae 2:143-163.

Świercz A (2004). The cement and lime industry and the occurrence of selected species of orchids. Przegląd Przyrodniczy 15(3-4):117-123.

Świercz A (2005). Storczyki a przemysł cementowy w regionie świętokrzyskim [Orchids and cement industry in the region Świętokrzyskie]. Parki Narodowe 2:24-26.

Świercz A (2006). Przegląd stanowisk wybranych gatunków z rodziny Orchidaceae w sąsiedztwie cementowni regionu świętokrzyskiego [Survey of selected species from the family Orchidaceae in the vicinity of the cement plant in the region of Kielce]. Regionalne Studia Ekologiczno-Krajobrazowe, Problemy Ekologii Krajobrazu 16, Warszawa, pp 433-440.

Świercz A (2007). Wpływ cementowni Ożarów (Przedgórze Iłżeckie) na zmianę składu gatunkowego zbiorowisk borowych w latach 1993-2003 [Effect of Ożarów cement plant (Przedgórze Itżeckie) on the changes floristic from 1993-2003]. Sylwan 5:52-59.

Szlachetko DL (1988). Storczykowate (Orchidaceae) we wschodniej części Pobrzeża Kaszubskiego. Zeszyty Naukowe Wydz BGiO UG Biologia 8:99-134. 
Szotkowski P (1987). Flora Miasta Głogówka na Śląsku Opolskim. Opolskie Towarzystwo Przyjaciół Nauk, Opole.

Tabaka L, Gavrilova G, Fatare I (1988). Flora sosudistych rastenij LatvijskojSSR. Zinatne, Riga.

Tafra D, Pandža M, Milović M (2012). Vascular flora of the town of Omiš. Natura Croatica 21(2):301-334.

The IUCN Red List of Threatened Species (2015). Version 2015-4. Retrieved 2015 January 16 from http://www.iucnredlist.org.

Tokarska-Guzik B (1997). Rozmieszczenie i zasoby roślin chronionych na terenie miasta Jaworzno [Distribution and resources of protected plants in the town of Jaworzno]. Acta Biologica Silesiaca 30(47):106-124.

Tokarska-Guzik B, Rostański A (1997). Flora naczyniowa miasta Katowic - ocena wstępna [Vascular flora of the city of Katowice preliminary assessment]. Acta Biologica Silesiaca 33(47):21-53.

Tokarska-Guzik B, Rostański A (1998). Flora naczyniowa miasta Czeladź [Vascular flora of the city Czeladź]. Acta Biologica Silesiaca 33(50):12-57.

Trzcińska-Tacik H (1979). Flora synantropijna Krakowa [Flora synanthropic of Kraków]. Habilitation Thesis, Jagiellonian University 32, Kraków.

Ullman I, Bannister P, Wilson JB (1998). Lateral differentiation and the role of exotic species in roadside vegetation in southern New Zealand. Flora 193:149-164.

Urbisz A, Urbisz A (1998). Rośliny chronione południowo-zachodniej części Wyżyny Śląskiej. Acta Biologica Silesiaca 33(50):113-142.

Vakhrameeva MG, Tatarenko IV (1998). Age structure of population of orchids with different life forms. Acta Universitatis Wratislaviensis Prace Botaniczne 75:129-139.

Van Calster H, Vandenberghe R, Ruysen M, Verheyen K, Hermy M, Decocq $G$ (2008). Unexpectedly high 20th century floristic losses in a rural landscape in northern France. Journal of Ecology 96:927936.

Vähä-Piikkiö I, Kurtto A, Hahkala V (2004). Species number, historical elements and protection of threatened species in the flora of Helsinki, Finland. Landscape Urban Planning 68:357-370.

van Kleef HH, van Duinen GJA, Verberk WCEP, Leuven RSEW, van der Velde G, Esselink H (2012). Moorland pools as refugia for endangered species characteristic of raised bog gradients. Journal for Nature Conservation 20:255-263.

Vitousek PM, Mooney HA, Lubchenco J, Melillo JM (1997). Human Domination of Earth's Ecosystems. Science 277:494-499.
Walker KJ (2007). The last thirty five years: recent changes in the flora of the British Isles. Watsonia 26: 291-302.

Wells TCE, Cox R (1991). Demographic and biological studies on Ophrys apifera: some results from a 10 year study. In: Wells TCE, Willems JH (Eds). Population ecology of terrestrial orchids. SPB Academic Publishing, The Hague pp 47-61.

Wika S (1986). Zagadnienia geobotaniczne środkowej części Wyżyny Krakowsko-Wieluńskiej [Issues Geobotanical the middle of the Krakow-Wielun Upland]. Prace Naukowe UŚ w Katowicach 815:1-156.

Witosławski P (2006). Atlas of distribution of vascular plants in Łódź. Wydawnictwo Uniwersytetu Łódzkiego, Łódź.

Wittig R, Wittig M (2007). Epipactis helleborine(L.) Crantz - the first (semi)ruderal orchid species of Central Europe. Feddes Repert 118(1-2):46-50.

Wołkowycki D (2003). Atlas rozmieszczenia roślin naczyniowych w Bielsku Podlaskim: (stan na lata 1996-1997) [Distribution atlas of vascular plants in Bielsk Podlaski: (1996-1997). Phytocoenosis. Supplementum Cartographiae Geobotanicae 17(15):237-247.

Woch MW (2012). New and rare synanthropic plant species of the Polish flora on dormant sedimentation ponds of the Siersza Power Plant. Fragmenta Floristica et Geobotanica Polonica 19(1):29-38.

Wyrzykiewicz-Raszewska M, Brzeg A, Kuświk H (2001). Interesujące stanowisko kruszczyka błotnego Epipactis palustris (L.) Crantz w Kozieglowach koło Poznania [An interesting locality of marsh helleborine Epipactis helleborine (L.) Crantz in Koziegtowy obok Poznania]. Roczniki AR Poznań 334, Botanica 4:215-220.

Yamaura Y, Royle JA, Shimada N, Asanuma S, Sato T,... Makino S (2012). Biodiversity of man-made open habitats in an underused country: a class of multispecies abundance models for count data. Biodiversity and Conservation 21:1365-1380.

Zavyalova LV (2010). A checklist of Chernihiv urban flora. Phytosociocenter, Kyiv.

Zielińska KM, Kiedrzyński M, Grzyl A, Rewicz A (2016). Forest roadsides harbour less competitive habitats for a relict mountain plant (Pulsatilla vernalis) in lowlands. Scientific Reports 6:31913.

Zvyagintseva KA (2013). Native fraction of Kharkov urban flora: analysis and annotated synopsis of flora. Phytodiversity of Eastern Europe 7(3):5-28. 